\title{
Effect of NPK levels on yield and yield components of cabbage (brassica oleracea L. Var. Capitata)
}

Baseerat Bibi ${ }^{1}$, Gohar Ayub ${ }^{1}$, Mohammad Ilyas ${ }^{1 *}$, Abida Bibi ${ }^{1}$, Manzoor Ahmad $^{2}$, Samia Mukhtar ${ }^{1}$ and Qurat ul Ain ${ }^{1}$

1. Department of Horticulture, The University of Agriculture, Peshawar-Pakistan

2. Department of Agriculture Bacha Khan University Charsadda-Pakistan

*Corresponding author's email: Ilyas_swati88@yahoo.com

Citation

Baseerat Bibi, Gohar Ayub, Mohammad Ilyas, Abida Bibi, Manzoor Ahmad, Samia Mukhtar and Qurat ul Ain. Effect of NPK levels on yield and yield components of cabbage (brassica oleracea L. Var. Capitata). Pure and Applied Biology. Vol. 5, Issue 2, 2016, pp234-239. http://dx.doi.org/10.19045/bspab.2016.50030

\begin{tabular}{llll}
\hline Received: 02/01/2016 & Revised: 09/02/2016 & Accepted: 15/02/2016 & Online First: 19/02/2016
\end{tabular}

\section{Abstract}

Effect of NPK levels on yield and yield components of cabbage was studied at Horticulture Ornamental Nursery, The University of Agriculture, Peshawar. The experiment was laid out in Randomized Complete Block (RCB) Design with three replications. A total of sixteen treatments were replicated thrice, row-row and plant-plant distance were kept $60 \mathrm{~cm}$ and $45 \mathrm{~cm}$ respectively. Nitrogen was applied at the rate of $0,50,60$ and $70 \mathrm{~kg} \mathrm{ha}^{-1}$, while phosphorus and potassium was applied at the rate of 90 and $60 \mathrm{~kg} \mathrm{ha}^{-1}$ respectively. The fertilizer level (70-90-60kg NPK ha-1) gave significant results with regard to curd weight plant ${ }^{-1}(976 \mathrm{~g})$, curd diameter plant ${ }^{-1}$ $(13.67 \mathrm{~cm})$, yield plot $^{-1}(5.87 \mathrm{~kg})$, total yield ha ${ }^{-1}\left(36.85\right.$ ton ha $\left.{ }^{-1}\right)$, while minimum values for these parameters were recorded in control. Significant values for the number of leaves plant ${ }^{-1}(24)$ and leaves weight $\operatorname{plant}^{-1}(751 \mathrm{~g})$ was recorded at fertilizer level $\left(70-90-60 \mathrm{~kg} \mathrm{NPK} \mathrm{ha}^{-1}\right)$. However plant height and survival percentage remain unaffected with the application of fertilizer. Thus among various levels used, nitrogen at the rate of $70 \mathrm{~kg} \mathrm{ha}^{-1}$ with phosphorus and potassium @90 and $60 \mathrm{~kg} \mathrm{ha}^{-1}$ is recommended for cabbage growers in Peshawar.

Key words: Cabbage; N; P; K; Yield

\section{Introduction}

Cabbage (Brassica oleracea L. var. Capitata.) is a member of cruciferae family and a useful vegetable. It belongs to the genus Brassica. Cabbage is dicotyledonous crop with fibrous and branched roots. Cabbage has originated from the wild, leafy, non- heading types, which were found growing in Europe. Headed cabbage are usually consumed as cooked vegetable, or eaten fresh as an ingredient of mixed
salads.It can be grown throughout the year in most parts of Africa [1]. Cabbage is easily grown under wide range of conditions and is adaptable to most areas of Africa [2]. Cabbage has less quantity of calories and protein, but has a large amount of potassium, sulpher, calcium, vitamin $\mathrm{A}, \mathrm{C}$, $B_{1}$ and $B_{2}[2,3]$.The green outer leaves of cabbage are richer in vitamin A, calcium and iron than the white inner leaves. Cabbage starts its reproductive growth with the 
changes in temperature, it is a cool season crop and produces flowers in the areas of mild winter. Temperature above $24^{\circ} \mathrm{C}$ is not suitable for cabbage production [4]. It can be grown by direct seeding method as well as by transplantation. By direct seeding method, plant will have more balanced roots, stem and leaf. While in transplants root setting in a new environment will be a challenging task, but transplants are best for higher and early yield [5].Cabbage is a bulky crop and requires high amount of nitrogen and potassium. Optimally cabbage requires $60-85 \mathrm{~kg} \mathrm{~N}^{-1}, 60-80 \mathrm{~kg} \mathrm{P}_{2} \mathrm{O}_{5} \mathrm{ha}^{-}$ 1, and $30-90 \mathrm{~kg} \mathrm{~K}_{2} \mathrm{O} \mathrm{ha}{ }^{-1}[6]$. For optimum growth of the cabbage, nutrients must be available in suitable quantity. Soil contains a lot of nutrients, but most of these are in unavailable form. Fertilizers are formulated to supply the nutrients already existing in the soil. The type of fertilizer and quantity depends on soil type, initial nutrient reserves in the soil and yield level. Maximum marketable heads of cabbage at fertilizer level of $60-120 \mathrm{~kg} \mathrm{~N}$ and $30-90 \mathrm{~kg} \mathrm{P}_{2} \mathrm{O}_{5}$ per hectare [7]. Similar recommendations were reported by [8]. Response of cabbage is incredible to nitrogen application and moderate to phosphorus. An increased yield and nutritional quality in cabbage was recorded, by the application of $60 \mathrm{~kg} \mathrm{ha}^{-1} \mathrm{~N}$ [9].

The production increases progressively with the increased amount of $\mathrm{N}$-fertilizer along with phosphorus fertilizer [10, 3].Nitrogen application at higher dose increases yield and quality of broccoli [11]. NPK at the rate of $120-90-60 \mathrm{~kg} \mathrm{ha}^{-1}$ increases cabbage yield and growth [12]. Application of NPK at the rate of 70,100 and $70 \mathrm{~kg} \mathrm{ha}^{-1}$ per hectare respectively increased the number of leaves per plant, size and weight of cabbage head significantly as compared with control treatment. [13] Increased levels of nitrogen with constant doses of phosphorus and potassium on Chinese cabbage increases yield [14].

\section{Materials and methods}

An experiment entitled " Effect of NPK levels on yield and yield components of cabbage " was carried out at Horticulture Ornamental Nursery, University of Agriculture, Peshawar. Cabbage cv. Golden Acre's seeds were sown in the pots on $3^{\text {rd }}$ November 2011. Soil samples were taken randomly from experimental area and analyzed for different nutrients. Ridges were raised $15 \mathrm{~cm}$ from the soil surface to provide drainage for the removal of surplus irrigation or excess rain water.

When seedlings attained a height of 10$15 \mathrm{~cm}$ then these were transplanted in the field at $1^{\text {st }}$ December. Healthy seedlings of uniform size were selected for transplantation. Experimental design was Randomized Complete Block (RCB) Design. A total of sixteen treatments were replicated thrice. Four different levels of nitrogen $\left(0,50,60,70 \mathrm{~kg} \mathrm{ha}^{-1}\right)$ with basal doses of phosphorus (90kg ha-1) and potassium $\left(60 \mathrm{~kg} \mathrm{ha} \mathrm{ha}^{-1}\right)$ were applied in experimental plot. Different parameters such as, curd weight $(\mathrm{g})$, curd diameter $(\mathrm{cm})$, yield $\operatorname{plot}^{-1}(\mathrm{~kg})$, total yield (tons ha ${ }^{-1}$ ) and number of leaves plant ${ }^{-1}$. ANOVA and LSD techniques were used in order to see any difference among the various fertilizer levels.

\section{Results and discussion}

Curd weight plant $^{-1}$ (g)

The statistical data containing curd weight per plant is given in (Table 1), Statistical analysis indicates that different NPK levels had significant effect on curd weight per plant. According to the (Table 1) highest curd weight plant $^{-1}(976.67 \mathrm{~g})$ was recorded at a fertilizer level $70-90-60 \mathrm{~kg}$ NPK ha-1 followed by (866g) and (836g) curd weight plant $^{-1}$ with fertilizer level 70-90-0kg NPK $\mathrm{ha}^{-1}$ and 60-90-60kg NPK ha-1 respectively. The minimum curd weight plant $^{-1}$ (493g) 
was recorded in control treatment. Application of $\mathrm{N}, \mathrm{P}$ and $\mathrm{K}$ increased the average curd weight plant ${ }^{-1}$ over the control treatment. The application of nitrogen with constant doses of $\mathrm{P}$ and $\mathrm{K}$ increased the carbohydrate and protein content of the curd, which possibly increased the curd weight. Fertilizer level 70-90-0kg NPK ha-1 gave better results it might be because of the fact that plant is getting appropriate amount of nitrogen and phosphorus. Yield at this application is near to highest yield but because of lack of potassium plant is unable to give the highest yield because once $\mathrm{CO}_{2}$ is converted in to sugar it have to be transported to the organs of plant for storage. The plant transportation system requires energy in the form of ATP which needs potassium for its synthesis. On the other hand fertilizer level 60-90-60kg NPK $\mathrm{ha}^{-1}$, despite of all basic nutrients cannot give highest yield. It is because of the low dose of nitrogen. As curd of the cabbage is made of the leaves and nitrogen is responsible for vegetative growth. That's why the combination of $70 \mathrm{~kg} \mathrm{ha}^{-1} \mathrm{~N}, 90 \mathrm{~kg}$ ha $^{-1} \mathrm{P}_{2} \mathrm{O}_{5}$ and $60 \mathrm{~kg} \mathrm{ha}^{-1} \mathrm{~K}_{2} \mathrm{O}$ showed best results. While the minimum head weight per plant may be due to the insufficient availability of NPK. These results are in agreement with [15-19], who have reported an increase in cabbage head weight with increased level of nitrogen.

\section{Curd diameter $(\mathrm{cm})$}

The statistical data pertaining to the curd diameter is presented in (Table 1). According to the statistical analysis different NPK levels had significant effect on curd diameter. Table 1 shows that mean highest curd diameter $(13.67 \mathrm{~cm})$ was recorded with the fertilizer level 70-90-60kg ha-1 NPK followed by $(13.33 \mathrm{~cm})$ and $(13.00 \mathrm{~cm})$ curd diameter at 60-90-60 $\mathrm{kg} \mathrm{ha}^{-1}$ NPK and 70-90$0 \mathrm{~kg} \mathrm{ha}^{-1} \mathrm{NPK}$ respectively. The minimum diameter plant $^{-1}(8 \mathrm{~cm})$ was recorded in control treatment. Among various levels of
NPK, the difference in curd diameter may be because of increased reserved substances in the leaves, resulting from increased supply of NPK. All of three basic elements work together to attain the best yield. Nitrogen is the building block of chlorophyll, enzymes and hormones. Phosphorus is a major component of ATP and ADP and once $\mathrm{CO}_{2}$ is converted in to sugar it has to be transported to organs of the plant for storage. The plant transportation system requires energy in the form of ATP which needs potassium for its synthesis. That's why the combination of $70 \mathrm{~kg} \mathrm{ha}^{-1} \mathrm{~N}, 90 \mathrm{~kg}$ $\mathrm{ha}^{-1} \mathrm{P}_{2} \mathrm{O}_{5}$ and $60 \mathrm{~kg} \mathrm{ha}^{-1} \mathrm{~K}_{2} \mathrm{O}$ showed best results. These results are in agreement with $[20,16,12]$, who studied the effect of different doses of NPK on cabbage \& found that curd diameter was more effected by increased NPK levels.

\section{Yield per plot $(\mathbf{k g})$}

The statistical data relating to the yield per plot is given in (Table 1). The statistical analysis shows that different NPK levels had significant effect on yield per plot. Highest yield plot $^{-1}(5.87 \mathrm{~kg})$ was observed with the fertilizer level $70-90-60 \mathrm{~kg}$ NPK $\mathrm{ha}^{-1}$, followed by $(5.33 \mathrm{~kg})$ and $(4.97 \mathrm{~kg})$ yield plot $^{-1}$ with 70-90-0kg NPK ha-1 and 60-90$60 \mathrm{~kg}$ NPK ha-1 respectively. The minimum yield plot $^{-1}(2.86 \mathrm{~kg})$ was recorded in control treatment. With the increased level of NPK, possibly curd accumulated more proteins \& carbohydrates, so an increase in curd weight ultimately increased yield plot $^{-1}$. The plot which got the optimum amount of basic elements gave highest yield because all the processes for optimum growth were continued and plant grows normally. While the plot with fertilizer level 70-90-0kg NPK $\mathrm{ha}^{-1}$ gave better results it might be because of the fact that plant is getting appropriate amount of nitrogen and phosphorus. Yield at this application is near to highest yield but because of lack of potassium plant is unable to give the highest yield. Fertilizer level 60- 
90-60kg NPK ha-1, despite of all basic nutrients cannot give highest yield. It might be because of the low dose of nitrogen. These results are in agreement with $[21,18$, 16], who found that the application of nitrogen fertilizers increased uniformity among the plots which ultimately increased yield.

\section{Total Yield ha-1 (tons)}

Statistical analysis revealed that different NPK levels had significant effect on total yield $\mathrm{ha}^{-1}$. According to the (Table 1) highest yield ha ${ }^{-1}$ (36.85 tons $\mathrm{ha}^{-1}$ ) was observed with the fertilizer level (70-90$60 \mathrm{~kg} \mathrm{ha}^{-1} \mathrm{NPK}$ ) followed by (30.86 tons ha $\left.{ }^{1}\right)$ and (30.83 tons $\left.\mathrm{ha}^{-1}\right)$ yield with 70-90-0kg $\mathrm{ha}^{-1}$ NPK and 60-90-60kg ha- ${ }^{-1}$ NPK respectively. The lowest yield (18.34 tons $\mathrm{ha}^{-1}$ ) was noted in control plot. It is obvious that the application of $\mathrm{N}, \mathrm{P}$ and $\mathrm{K}$ increased the yield $\mathrm{ha}^{-1}$ as compare to the control treatment. Increase or decrease in total yield ton $\mathrm{ha}^{-1}$ entirely depends upon yield per plot and the yield per plot was increased with the application of appropriate NPK level. The addition of nitrogen with phosphorus and potash significantly increased total yield per hectare. Highest yield was obtained from the plots with maximum rates of NPK [22].

Number of leaves plant ${ }^{-1}$

The data pertaining to the number of leaves per plant is given in (Table 1). According to the means highest number of leaves (24) were recorded with fertilizer level (70-90-0 $\mathrm{kg} \mathrm{NPK} \mathrm{ha-1)} \mathrm{followed} \mathrm{by} \mathrm{(23)} \mathrm{and} \mathrm{(22.67)}$ number of leaves plant ${ }^{-1}$ with fertilizer level 70-90-60kg NPK ha ${ }^{-1}$ and 70-0-0kg NPK ha1 respectively. The least number of leaves plant $^{-1}$ (15) were recorded in control treatment. As nitrogen is responsible for vegetative growth, and phosphorus for leaf expansion and increasing leaves number so there is a possibility of low nitrogen and phosphorus availability to those plants, which had low number of leaves. Results obtained from the fertilizer levels $70-0-0 \mathrm{~kg}$ NPK ha ${ }^{-1}$ and70-90kg NPK ha ${ }^{-1}$ revealed that nitrogen alone and in combination also gave better results for number of leaves so the basic element for leaves formation is nitrogen. The combination of $70 \mathrm{~kg} \mathrm{ha}^{-1} \mathrm{~N}$, $90 \mathrm{~kg} \mathrm{ha}^{-1} \mathrm{P}_{2} \mathrm{O}_{5}$ and $0 \mathrm{~kg} \mathrm{ha}^{-1} \mathrm{~K}_{2} \mathrm{O}$ showed best results. Similar results were obtained by $[23,24,16,12]$.

Table 1. Cabbage curd weight (g), Curd diameter plant ${ }^{-1}(\mathrm{~cm})$, Yield per plot (kg), Total Yield ha ${ }^{-1}$ (tons) and Number of leaves plant ${ }^{-1}$ as affected by different levels of NPK

\begin{tabular}{l|l|l|l|l|l}
\hline $\begin{array}{l}\text { Treatments } \\
\text { N:P:K kg ha }\end{array}$ & $\begin{array}{l}\text { Curd weight } \\
\text { plant }^{-1}(\mathbf{g})\end{array}$ & $\begin{array}{l}\text { Curd diameter } \\
\text { plant }^{-1}(\mathbf{c m})\end{array}$ & $\begin{array}{l}\text { Yield per } \\
\text { plot }(\mathbf{k g})\end{array}$ & $\begin{array}{l}\text { Total Yield } \\
\text { ha }^{-1}(\text { tons) }\end{array}$ & $\begin{array}{l}\text { Number of } \\
\text { leaves plant }\end{array}$ \\
\hline $0: 0: 0$ & $493.00 \mathrm{~d}$ & $8.00 \mathrm{~d}$ & $2.86 \mathrm{~d}$ & $18.34 \mathrm{e}$ & $5.67 \mathrm{c}$ \\
\hline $50: 0: 0$ & $514.00 \mathrm{bcd}$ & $10.00 \mathrm{bcd}$ & $3.07 \mathrm{~cd}$ & $18.96 \mathrm{cde}$ & $17.33 \mathrm{c}$ \\
\hline $60: 0: 0$ & $516.67 \mathrm{bcd}$ & $11.00 \mathrm{abc}$ & $3.09 \mathrm{bcd}$ & $19.08 \mathrm{cde}$ & $19.33 \mathrm{abc}$ \\
\hline $70: 0: 0$ & $591.00 \mathrm{bc}$ & $11.67 \mathrm{abc}$ & $3.60 \mathrm{bcd}$ & $22.19 \mathrm{cde}$ & $22.67 \mathrm{ab}$ \\
\hline $0: 90: 0$ & $501.00 \mathrm{~cd}$ & $9.00 \mathrm{~cd}$ & $3.02 \mathrm{ab}$ & $18.64 \mathrm{de}$ & $17.67 \mathrm{c}$ \\
\hline $50: 90: 0$ & $625.00 \mathrm{ab}$ & $12.00 \mathrm{ab}$ & $4.37 \mathrm{ab}$ & $24.91 \mathrm{bcd}$ & $19.33 \mathrm{abc}$ \\
\hline $60: 90: 0$ & $699.33 \mathrm{ab}$ & $12.67 \mathrm{ab}$ & $4.17 \mathrm{ab}$ & $28.05 \mathrm{ab}$ & $19.67 \mathrm{abc}$ \\
\hline $70: 90: 0$ & $866.00 \mathrm{ab}$ & $13.00 \mathrm{ab}$ & $5.33 \mathrm{ab}$ & $30.86 \mathrm{ab}$ & $24.00 \mathrm{a}$ \\
\hline $0: 0: 60$ & $602.33 \mathrm{bc}$ & $10.67 \mathrm{abcd}$ & $3.57 \mathrm{bc}$ & $22.01 \mathrm{cde}$ & $17.67 \mathrm{c}$ \\
\hline $50: 0: 60$ & $624.67 \mathrm{abc}$ & $12.00 \mathrm{abc}$ & $3.73 \mathrm{bc}$ & $23.04 \mathrm{cde}$ & $18.33 \mathrm{bc}$ \\
\hline $60: 0: 60$ & $645.00 \mathrm{ab}$ & $12.33 \mathrm{ab}$ & $3.89 \mathrm{abc}$ & $24.01 \mathrm{bcd}$ & $18.67 \mathrm{bc}$ \\
\hline $70: 0: 60$ & $737.00 \mathrm{ab}$ & $12.67 \mathrm{ab}$ & $4.40 \mathrm{ab}$ & $27.13 \mathrm{abc}$ & $19.33 \mathrm{abc}$ \\
\hline $0: 90: 60$ & $764.33 \mathrm{ab}$ & $10.00 \mathrm{bcd}$ & $4.60 \mathrm{abc}$ & $28.19 \mathrm{ab}$ & $17.67 \mathrm{c}$ \\
\hline $50: 90: 60$ & $768.67 \mathrm{ab}$ & $13.00 \mathrm{ab}$ & $4.64 \mathrm{ab}$ & $28.64 \mathrm{ab}$ & $19.67 \mathrm{abc}$ \\
\hline
\end{tabular}




\begin{tabular}{l|l|l|l|l|l}
\hline 60:90:60 & $836.00 \mathrm{ab}$ & $13.33 \mathrm{a}$ & $4.97 \mathrm{ab}$ & $30.83 \mathrm{ab}$ & $19.67 \mathrm{abc}$ \\
\hline 70:90:60 & $976.67 \mathrm{a}$ & $13.67 \mathrm{a}$ & $5.87 \mathrm{a}$ & $36.85 \mathrm{a}$ & $23.00 \mathrm{ab}$ \\
\hline LSD at 5\% & $\mathbf{3 1 6 . 7 3 9}$ & $\mathbf{2 . 5 6 8}$ & $\mathbf{1 . 9 6 4}$ & $\mathbf{1 0 . 5}$ & $\mathbf{4 . 2 6 5}$ \\
\hline
\end{tabular}

Means followed by different letter (s) within each category are significantly different using LSD test at $\mathrm{P} \leq 0.05$. ns $=$ non-significant

\section{Conclusion and recommendations}

During the course of experiment the performance of several levels of NPK were evaluated. On the basis of results obtained, it is concluded that the application of NPK significantly increased the growth and yield of cabbage. Fertilizer application at the rate of $70 \mathrm{~kg} \mathrm{~N}, 90 \mathrm{~kg}_{2} \mathrm{O}_{5}$ and $60 \mathrm{~kg} \mathrm{~K}_{2} \mathrm{O}$ ha $^{-1}$ was effective in improving the growth and yield components such as curd weight, curd diameter, yield plot $^{-1}$, and total yield. Plots without NPK or lacking any one of these didn't give best yield. Therefore the fertilizer level 70-90-60 kg ha ${ }^{-1} \mathrm{NPK}$ is recommended for the cabbage growers in Peshawar.

\section{Authors' contributions}

Design the experiment: G. Ayub \& M. Ilyas. Data collection and analysis: B. Bibi, Abida. Technical help, data analysis and revision of the manuscript: M. Ahmad, S. Mukhtar. Downloaded the related review, data collection and interpretation of the data: Q.Ain.

\section{References}

1. Grubben GJH \& Denton OA (2004). Plant resource of Tropical Africa and vegetables. CTA Wageningen, Netherlands. 668.

2. Smith M (1995). Soil types effects on Growth and dry matter production of spring onion. J Horti Sci Tech 77: 340.

3. Mohans BK \& Hossain MM (1998). Effects of nitrogen and phosphorus on cabbage. Orissa J Horti 26(1):106-108.

4. Kahn BA, Edelson J \& Damicone JP (2007). Cole crop production (Broccoli, Cabbage, and Cauliflower). Oklahoma Cooperative Extension Service.
5. Leskovar DI \& Catliffe DJ (1993). Comparison of plant establishment method, transplant or direct seeded on growth and yield of bell pepper. Amer Soc Hort Sci 118:17- 22.

6. Shika A \& Doug W (2001). Cabbage postharvest handling and storage. NSW.

7. Singh and Naik 1990. Response of cabbage to plant spacing and nitrogen level on growth and yield of cabbage cultivars. Hort Absts 58 (10): 729.

8. Morris VS (1950). Effect of NPK on Cabbage Yield. Hort Soc 33-39.

9. Bhardwaj ML, Raj H \& Koul BL (2000). Yield response and economics of Organics sources and inorganic source in tomato (Lycopersicom esculetum), okra (Hibiscus esculentus) and cabbage (B. oleraceaeva and $B$. Oleracea varbotytis). Ind J Agri Sci 70(10): 653656.

10. Humadi FM \& Hadi HAA (1988). Effect of different source and rates of nitrogen and phosphorus fertilizer on the yield and quality of cabbage. J Agric Water Reso Plant Prod 7(2): 249-59

11. Moniruzzaman M, Rahman SML, Kibria MG, Rahman MA \& Hossain MM (2007). Effect of Boron and Nitrogen on Yield and Hollow stem of Broccoli. Soil. Nature 1(3): 24-29.

12. Din M, Qasim M \& Alam M (2005). Effect of different levels of N, P and K on the growth and yield of cabbage. J Agri Res 45(2): 171- 176.

13. Hamid A (2002). Response of cabbage at different sowing dates, fertilizer application, plant spacing and seed yield grown under temperate conditions of 
Azad Kashmir. Pak J Arid Agri 5(2): 37-41.

14. Ishtiaq M. \& Ullah J (2001). Response of Chinese cabbage cultivars to different levels of nitrogen with constant doses of phosphorus and potassium. Sar J Agri 17(1): 81-85.

15. Peck NH, Grunes LD, Welch RM \& Macdenald GE (1980). Nutritional quality of vegetable crop as affected by phosphorus and zinc fertilizer. Agron $J$ 72(3): 528-534.

16. Ghanti P, Sounda G, Jana P K \& Som M G (1982). Effect of levels of nitrogen phosphorus \& spacing on the yield characters of cabbage. Veg Sci 9: 1-4.

17. Soundy P (1996). Lettuce transplant root \& shoot growth \& development in relation to NPK \& water management.

18. Ranjit C (2010). Physiological attributes of cabbage as influenced by different sources of nutrients. Res $J$ Agri Sci 1(4): 318-321.
19. Gupta A 1987. Effect of nitrogen \& irrigation on cabbage production. Indian $J$ of Hort 44: 241-244.

20. Srinivas K (1982). Growth yield of cabbage as spacing and fertilizer. Singapore J Prim Indus 10(1): 58-63.

21. Evaraarts AP \& Demoel CP (1998). Effect of nitrogen and method of application on the yield and quality of white cabbage. European $J$ Agron 9:203-211.

22. Dudnik SA, Antonov AV, \& Pleshkov KK (1981). Effectiveness of fertilization in early cabbage under irrigation. Hort Abst 51(8): 29- 30.

23. Halim GMA \& Ahmed MS (1989). Effects of different levels of NPK on the growth \& yield of cabbage. BAAS Dhaka (Bangladesh): 126.

24. Tiwari KN, Singh PK \& Mal PK (2003). Effect of drip irrigation on yield of cabbage (Brassica oleraceaL. var. capitata) under mulch and non-mulch conditions. Agric. Water Manag 58: 19-28. 